Vidyodaya J., of Sci., (1992) Vol. 4, No. 1 pp: 209 - 219

\title{
MINERAL NUTRITION OF Cymbopogon nardus (L) Rendle: \\ PART II. EFFECTS OF MAGNESIUM AND PHOSPHORUS NUTRITION ON THE FRACTIONAL COMPOSITION OF ESSENTIAL OIL.
}

\author{
S. S. Ranaweera* and W. P. Thilakaratne \\ Department of Botany, \\ University of Sri Jayewardenepura, \\ Nugegoda, Sri Lanka.
}

Date Received : 25-06-1992.

Date Accepted : $10-03-1993$

\begin{abstract}
Results obtained from a fertilizer experiment conducted with thirteen treatments indicate the positive effect of phosphorus and magnesium nutrition on the yield and the fractional composition of essential oil of Cymbopogon nardus. Phosphorus nutrition has increased the "total geraniol" (total acetylisable compounds) in oil. Magnesium in combination with phosphorus fertilizers significantly increased the total geraniol at the second harvest. The increase of total geraniol was always accompanied by the decrease of total hydrocarbons, which indicates the better utilization of monoterpenes in biosyntheis of constituents of total geraniol in oil as a result of phosphorus nitrition. Phosphorus content in leaves has positive relationships with total geraniol $(r=+0.5)$, essential oil yield $(r=+0.58)$ and output of total geraniol $(\mathrm{r}=+0.59)$. The optimum phosphorus concentrations in leaves after four months of planting that produced maximum yields of essential oil and total geranisl by this crop were found to be in the range of $0.23-0.26 \%$.
\end{abstract}

Key words: Cymbopogon nardus, Magnesium and phcsphorus nutrition, Fractional composition of essential oil, Biosynthesis, Total acetylisables.

\section{Introduction}

Citronella oil is the essential oil obtained from citronella grass which is botanically classified into two species: Cymbopogon winterianus Jowitt and Cymbopogon nardus (L) Rendle (Abeywikreme, 1959; Guenther, 1950). Sri Lanka is one of the major citronella oil producing countries and the "Ceylon citronella" species, Cymbopogon nardus has been cultivated commercially in Sri Lanka for over a century (Brown and Matthews, 1951).

- Corresponding Author. 
These two citronella species are distinguished morphologically, anatomically (Iruthayathas et. al, 1977) and chemically (Jowitt, 1908; Wijesekera, 1973). One of the striking differences observed was the presence of monoterpene hydrocarbons amounting to more than $20 \%$ of the oil in C. nardus as against $3-4 \%$ in C. winterianus. Cymbopogon winterianus contained around $85 \%$ total acetylisable compounds expressed as "total geraniol" which determines the market quality of citronella oil (Brown and Matthews, 1951). Cymbopogon nurdus on the other hand was reported to contain $55-65 \%$ total alcohols (Wijesekera, 1973).

Several posphorylation reactions are involved in the biosynthesis of essential oils in plants. For example the conversion of mevalonic acid to squalene in yeast was shown to be dependant on adenosine triphosphate (ATP) and reduced pyridine nucleotides and magnesium ions (Hanson, 1967). Possible operation of an essential oil biosynthetic pathway via neryl or geranypyrophosphate in Cymbopogon nardus has been suggested (Wijesekera, 1973).

The positive effect of magnesium and phosphorus nutrition on the essential oil production by Cymbopogon nardus has been reported (Ranaweera and Thilakaratne, 1992). However, no recorded information is available on the effects of phosphorus and magnesium nutrition on the fractional composition of citronella oil. As such, this study was undertaken to examine the effects of phosphorus and magnesium nutrition of Cymbopogon nardus, on the fractional composition of essential oil in view of improving its market quality.

\section{Materials and Methods}

\section{Experimental Procedure:}

A fertilizer experiment was conducted according to the scheme indicated in Table 1. The experiment had thirteen fertilizer treatments and eight replicates. The surface $20 \mathrm{~cm}$. of Yellow podsolic soil $(\mathrm{pH}=5.1)$ with low phosphorus (5.7mg $\mathrm{P}_{2} \mathrm{O}_{5} / 100 \mathrm{~g}$ soil) and magnesium (10mg $\mathrm{Mg} / 100 \mathrm{~g}$ soil) content, was air dried, sieved and mixed with appropriate fertilizers according to different fertilizer treatments. Each pot was filled with $3 \mathrm{~kg}$ of soil and planted with two slips of Cymbopogon nardus and later thinned down to one. The crop was harvested twice. The first harvest was made after four months and the second harvest after seven months of planting. For harvesting, the plant parts above ground was cut. 
Table 1 Fractional compostion of essential oils of Cymbopogon nardus as affected by phosphorus and magnesium nutrition.

\begin{tabular}{|c|c|c|c|c|c|c|c|c|c|c|c|c|c|c|}
\hline \multirow{2}{*}{ Treatment } & \multirow{2}{*}{$\begin{array}{c}\text { Total } \\
\text { Geraniol }\end{array}$} & \multirow{2}{*}{$\begin{array}{c}\text { Total } \\
\text { Hydrocarbons }\end{array}$} & \multicolumn{12}{|c|}{ Constituents of total geraniol } \\
\hline & & & $\begin{array}{l}\text { Citro } \\
\text { nallal }\end{array}$ & Linalool & $\begin{array}{l}\text { Linalyl } \\
\text { acetate }\end{array}$ & $\begin{array}{r}\text { Borneol } \\
\text { Fi }\end{array}$ & $\begin{array}{l}\text { Geranyl } \\
\text { formate } \\
\text { First harvest }\end{array}$ & $\begin{array}{c}\text { Citronel } \\
\text { lool }\end{array}$ & Nerol & $\underset{b}{\text { Geraniol }}$ & $\begin{array}{l}\text { Geranyl } \\
\text { butarate }\end{array}$ & $\begin{array}{l}\text { Methyl } \\
\text { euginol }\end{array}$ & Elemol & $\begin{array}{r}\text { Me-iso } \\
\text { eugino }\end{array}$ \\
\hline $\begin{array}{l}\text { Control } \\
P_{1} \\
P_{1}+M_{1} \\
P_{1}+M g_{2} \\
P_{2} \\
P_{2}+M_{1} \\
P_{2}+M_{2} \\
P_{3} \\
P_{3}+M_{1} \\
P_{3}+M g_{2} \\
P_{4} \\
P_{4}+M_{1} \\
P_{4}+\mathbf{M g}_{2}\end{array}$ & $\begin{array}{l}46.81 \\
40.85 \\
53.72 \\
58.33 \\
48.16 \\
42.74 \\
47.79 \\
50.48 \\
48.36 \\
42.83 \\
65.57 \\
56.38 \\
52.53\end{array}$ & $\begin{array}{r}38.51 \\
27.13 \\
18.61 \\
9.40 \\
22.08 \\
26.68 \\
12.63 \\
4.01 \\
8.11 \\
15.28 \\
2.61 \\
14.31 \\
13.98\end{array}$ & $\begin{array}{l}1.65 \\
1.12 \\
1.76 \\
1.56 \\
1.67 \\
0.79 \\
1.13 \\
1.53 \\
1.38 \\
1.51 \\
1.38 \\
1.68 \\
1.94\end{array}$ & $\begin{array}{l}4.08 \\
3.08 \\
2.82 \\
3.51 \\
2.57 \\
2.27 \\
2.98 \\
4.79 \\
4.81 \\
4.28 \\
6.41 \\
2.63 \\
7.18\end{array}$ & $\begin{array}{l}1.06 \\
1.52 \\
1.18 \\
1.25 \\
2.21 \\
097 \\
1.29 \\
0.49 \\
0.73 \\
1.07 \\
0.79 \\
1.53 \\
0.87\end{array}$ & $\begin{array}{r}11.99 \\
8.48 \\
14.26 \\
11.77 \\
12.79 \\
13.64 \\
7.49 \\
10.65 \\
11.61 \\
14.69 \\
11.35 \\
12.71 \\
19.36\end{array}$ & $\begin{array}{l}1.69 \\
1.50 \\
1.85 \\
2.36 \\
1.69 \\
1.27 \\
1.41 \\
3.12 \\
1.96 \\
1.79 \\
2.89 \\
2.33 \\
1.52\end{array}$ & $\begin{array}{r}4.15 \\
5.90 \\
5.18 \\
4.86 \\
4.02 \\
3.18 \\
6.54 \\
9.30 \\
7.97 \\
4.36 \\
10.33 \\
5.01 \\
3.80\end{array}$ & $\begin{array}{l}1.04 \\
1.22 \\
1.34 \\
1.29 \\
1.18 \\
1.09 \\
1.32 \\
1.69 \\
1.49 \\
1.09 \\
1.54 \\
1.24 \\
1.05\end{array}$ & $\begin{array}{r}6.98 \\
11.21 \\
9.25 \\
10.75 \\
7.83 \\
5.23 \\
12.15 \\
9.89 \\
8.70 \\
7.40 \\
11.63 \\
11.21 \\
4.61\end{array}$ & $\begin{array}{l}1.89 \\
2.56 \\
2.29 \\
3.06 \\
2.60 \\
2.43 \\
3.18 \\
3.38 \\
2.93 \\
1.81 \\
3.54 \\
2.33 \\
1.37\end{array}$ & $\begin{array}{l}1.32 \\
1.51 \\
1.50 \\
1.97 \\
1.34 \\
1.06 \\
1.51 \\
2.15 \\
1.65 \\
1.23 \\
2.15 \\
1.56 \\
0.79 \\
\end{array}$ & $\begin{array}{r}6.21 \\
7.02 \\
8.96 \\
11.62 \\
8.18 \\
6.49 \\
5.72 \\
8.64 \\
8.17 \\
5.94 \\
10.01 \\
9.84 \\
6.72 \\
\end{array}$ & $\begin{array}{l}4.75 \\
3.13 \\
4.83 \\
4.33 \\
4.68 \\
4.32 \\
3.07 \\
4.15 \\
5.66 \\
5.06 \\
3.55 \\
4.31 \\
7.12 \\
\end{array}$ \\
\hline \multicolumn{15}{|c|}{ Second harvest } \\
\hline $\begin{array}{l}\text { Control } \\
\mathbf{P}_{1} \\
\mathbf{P}_{1}+\mathbf{M g}_{1} \\
\mathbf{P}_{1}+\mathbf{M g} 2 \\
\mathbf{P}_{2} \\
\mathbf{P}_{2}+\mathbf{M g}_{1} \\
\mathbf{P}_{2}+\mathbf{M g} \\
\mathbf{P}_{3} \\
\mathbf{P}_{3}+\mathbf{M g}_{1} \\
\mathbf{P}_{3}+\mathbf{M g}_{2} \\
\mathbf{P}_{4} \\
\mathbf{P}_{4}+\mathbf{M g}_{1} \\
\mathbf{P}_{4}+\mathbf{M g}_{2}\end{array}$ & $\begin{array}{l}34.23 \\
52.27 \\
47.56 \\
56.85 \\
58.80 \\
49.93 \\
61.58 \\
69.17 \\
64.87 \\
62.90 \\
61.19 \\
68.78 \\
65.84\end{array}$ & $\begin{array}{r}44.63 \\
19.16 \\
23.08 \\
18.01 \\
20.36 \\
25.67 \\
14.93 \\
8.96 \\
7.25 \\
9.36 \\
3.15 \\
7.73 \\
3.08\end{array}$ & $\begin{array}{l}1.14 \\
1.22 \\
1.34 \\
1.57 \\
2.18 \\
1.82 \\
1.91 \\
2.09 \\
1.58 \\
3.26 \\
1.37 \\
2.08 \\
1.40\end{array}$ & $\begin{array}{l}2.97 \\
3.40 \\
4.69 \\
5.26 \\
5.22 \\
5.36 \\
6.04 \\
6.87 \\
4.35 \\
6.48 \\
4.41 \\
5.85 \\
4.28\end{array}$ & $\begin{array}{c}1.41 \\
1.05 \\
0.92 \\
5.26 \\
0.69 \\
1.98 \\
2.11 \\
1.27 \\
0.63 \\
1.84 \\
- \\
0.68\end{array}$ & $\begin{array}{r}9.03 \\
9.43 \\
10.50 \\
5.26 \\
16.63 \\
14.38 \\
20.08 \\
18.43 \\
12.65 \\
25.31 \\
11.49 \\
16.74 \\
12.63\end{array}$ & $\begin{array}{l}1.38 \\
2.13 \\
1.81 \\
5.26 \\
1.75 \\
1.54 \\
1.76 \\
2.46 \\
-\overline{1.38} \\
2.82 \\
2.84 \\
2.94\end{array}$ & $\begin{array}{r}2.98 \\
6.3 \\
5.08 \\
5.26 \\
6.53 \\
4.44 \\
5.67 \\
7.29 \\
11.01 \\
4.08 \\
8.11 \\
8.74 \\
7.68\end{array}$ & $\begin{array}{l}0.81 \\
1.29 \\
1.28 \\
5.26 \\
1.17 \\
1.07 \\
1.14 \\
1.47 \\
1.32 \\
1.02 \\
1.55 \\
1.49 \\
1.39\end{array}$ & $\begin{array}{r}5.6 \\
11.66 \\
8.38 \\
5.26 \\
9.77 \\
5.85 \\
6.89 \\
10.91 \\
12.17 \\
3.63 \\
11.44 \\
10.75 \\
12.18\end{array}$ & $\begin{array}{l}1.39 \\
2.87 \\
2.05 \\
5.26 \\
2.28 \\
1.56 \\
1.89 \\
2.44 \\
3.60 \\
1.20 \\
3.74 \\
3.03 \\
8.87\end{array}$ & $\begin{array}{l}0.94 \\
1.69 \\
1.43 \\
1.73 \\
1.37 \\
0.91 \\
1.07 \\
1.45 \\
1.80 \\
0.47 \\
2.44 \\
2.06 \\
2.23\end{array}$ & $\begin{array}{r}3.75 \\
8.10 \\
6.35 \\
7.90 \\
7.66 \\
5.77 \\
7.35 \\
8.82 \\
9.90 \\
6.54 \\
9.85 \\
10.48 \\
11.34\end{array}$ & $\begin{array}{l}2.79 \\
3.04 \\
3.67 \\
3.40 \\
4.50 \\
5.21 \\
5.63 \\
5.62 \\
5.81 \\
7.63 \\
3.96 \\
4.63 \\
6.71\end{array}$ \\
\hline
\end{tabular}


Analytical methods:

The total phosphorus content in leaves was determined colorimetrically by vanadomolybdate procedure (Peterburski, 1968). The Essential oil content of leaves was determined by steam distillation, using a Cleavanger distillation apparatus and the oil content was expressed in cleavanger units (Brain and Turner, 1975) and the output of total geraniol was expressed in milli litres per 100 plants.

\section{Gas chromatographic analysis:}

GLC fractionation of essential oils was carried out on a Gas chromatographVarian 2700 with F.I.D.; Column: Carbowax 20M 10\% coated on Gaschrom $\mathrm{Q}(3 \mathrm{M} \mathrm{x} 20 \mathrm{~mm})$; Injection block temp. $230^{\circ} \mathrm{C}$; Detector oven temp. $230^{\circ} \mathrm{C}$; Carrier gas (Argon) $30 \mathrm{ml} / \mathrm{min}$; Samples $(0.2 \mu \mathrm{l})$, with programming from 100 to $230^{\circ} \mathrm{C}$ at $2^{\circ} \mathrm{C} / \mathrm{min}$; Recorder, Shimadsu chromatopak $6 \mathrm{~A}$.

\section{Statistical methods:}

Experimental data were analysed using ANOVA method at the $5 \%$ level of significance. Regression analysis of data was carried out by fitting the data to non-liniar regression equations with the aid of MINITAB statistical package.

\section{Results}

The "total geraniol" content of oil was significantly affected by phosphorus and magnesium nutrition. Results presented in Table 1 , indicate that the app'ication of $\mathrm{P}_{3}$ and $\mathrm{P}_{4}$ levels have significantly increased the total geraniol at the first harvest from $46.81 \%$ in control to $50.48 \%$ and $65.57 \%$ respectively. The effect of phosphorus fertilizers on the total geraniol was more marked at the second harvest. At the second harvest all phosphorus levels have significantly increased the total geraniol over the control. The $\mathbf{P}$ level has picduced the highest geraniol content of $69.17 \%$ As shown in Figure 1 and Table 3, a positive relationship was observed between the leaf phosphorus and the total geraniol in oil $(r=+0.5)$. As observed in Table 1, this increase of total geraniol has occured mainly due to the increased accumulation of borneol, geraniol, citronelool, geranyl butarate, elamol, linalool, nerol and methyl iso - euginol constituents in oil. As indicated in Table 3, the phosphorus content in leaves is correlated well with the accumulation of linalool $(\mathrm{r}=+0.71)$, borneol $(r=+0.53)$ and methyl iso-euginol $(r=+0.51)$ in oil. 


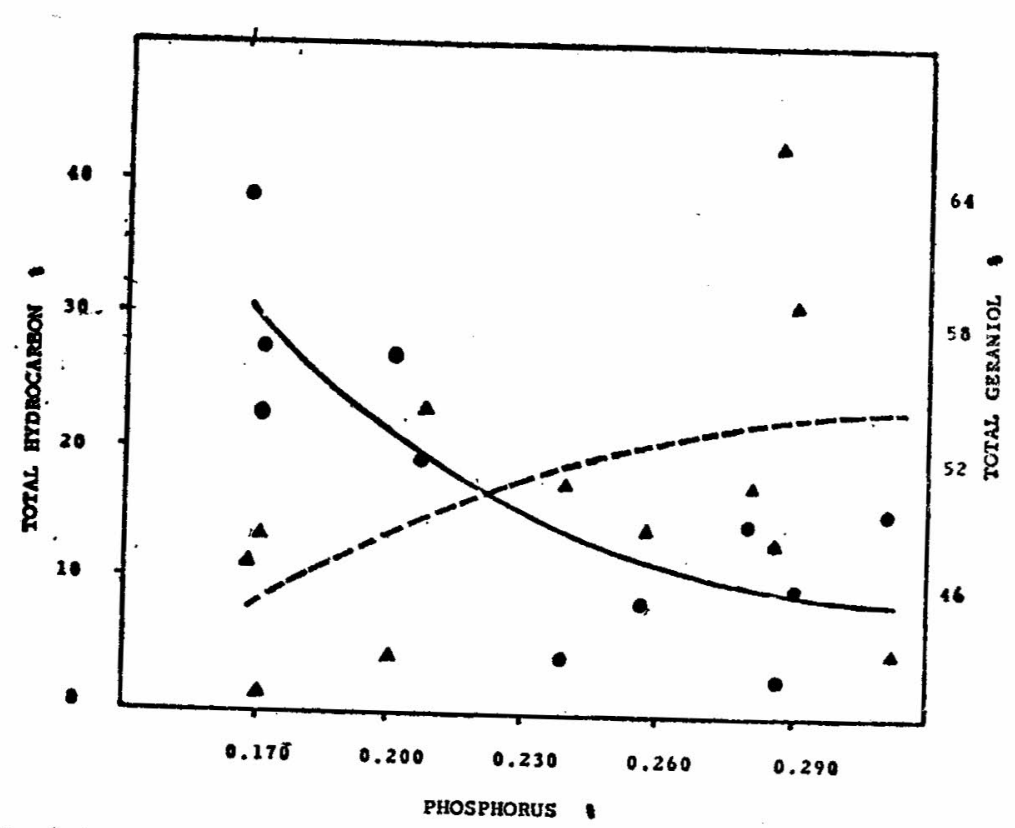

IIgure i 1 The relatlonshtp betwoen phosphorus content in leaves versus (1) total hydrocarbon (

The positive effect of magnesium on the total geraniol was observed at the first harvest when it was applied in combination with $P_{1}$ level. Magnesium tend to decrease the total geraniol with other phosphorus levels. However, at the second harvest, magnesium $\left(\mathrm{Mg}_{2}\right.$ level) showed a positive effect on the total geraniol content. Fertilizer combinations, $\mathrm{P}_{1}+\mathrm{Mg}_{2}$ and $\mathrm{P}_{4}+\mathrm{Mg}_{2}$ increased the total geraniol by $4.58 \%$ and $4.65 \%$ over their respective controls. As shown in the Fig. 4, the borneol content in oil was further increased when magnesium was applied together with phosphorus fertilizers.

The increase of total geraniol due to magnesium and phosphorus nutrition was accompanied by the decrease of hydrocarbon content in oil. As indicated in Table 1, total hydrocarbon content in oil was decresed from $38.51 \%$ in control to $27.13,22.08,4.01$ and $2.61 \%$ as a result of the application of $P_{1}, P_{2}, P_{3}$ and $\mathrm{P}_{4}$ levels respectively. The same tendency was observed at the second harvest. The negative relationship was observed between the total geraniol and total hydrocarbon contents in oil $(r=-0.6)$ at the first harvest and $(r=-0.9)$ at the second harvest (Fig. 2). 
Table - 2 Phosphorus content in leaves, essential oil yield, total geraniol and output of geraniol of Cymbopogon nardus as affected by $\mathbf{P}$ and $\mathrm{Mg}$ nutrition

\begin{tabular}{|c|c|c|c|c|c|c|c|c|c|c|}
\hline \multirow[b]{2}{*}{ Treatment } & \multirow{2}{*}{$\begin{array}{c}\text { Phosphorus } \\
\text { concentration } \\
\text { in leaves }(\%) \\
\text { ( first harvest) }\end{array}$} & \multicolumn{3}{|c|}{ Essential oil yield (ml/100 plants) } & \multicolumn{2}{|c|}{ Total geraniol $(\%)$} & \multicolumn{4}{|c|}{ Output of geraniol (ml/100 plants) } \\
\hline & & $\begin{array}{l}\text { First } \\
\text { harvest }\end{array}$ & $\begin{array}{l}\text { Second } \\
\text { harvest }\end{array}$ & Total & $\begin{array}{c}\text { First } \\
\text { harvest }\end{array}$ & $\begin{array}{l}\text { Second } \\
\text { harvest }\end{array}$ & Total & $\begin{array}{l}\text { First } \\
\text { harvest }\end{array}$ & $\begin{array}{c}\text { Second } \\
\text { h:rvest }\end{array}$ & Total \\
\hline $\begin{array}{l}\text { Control } \\
\mathrm{P}_{1} \\
\mathrm{P}_{1}+\mathrm{Mg}_{1} \\
\mathrm{P}_{1}+\mathrm{Mg}_{2} \\
\mathrm{P}_{2} \\
\mathrm{P}_{2}+\mathrm{Mg}_{1} \\
\mathrm{P}_{2}+\mathrm{Mg}_{2} \\
\mathrm{P}_{3} \\
\mathrm{P}_{3}+\mathrm{Mg}_{1} \\
\mathrm{P}_{3}+\mathrm{Mg}_{2} \\
\mathrm{P}_{4} \\
\mathrm{P}_{4}+\mathrm{Mg}_{1} \\
\mathrm{P}_{4}+\mathbf{M g}_{2}\end{array}$ & $\begin{array}{l}0.168 \\
0.170 \\
0.206 \\
0.290 \\
0.170 \\
0.200 \\
2.86 \\
0.238 \\
0.256 \\
0.312 \\
0.286 \\
0.280 \\
0.452\end{array}$ & $\begin{array}{l}13.44 \\
28.80 \\
42.70 \\
34.06 \\
24.96 \\
44.16 \\
61.44 \\
55.18 \\
56.14 \\
33.60 \\
69.12 \\
44.62 \\
73.42\end{array}$ & $\begin{array}{r}42.70 \\
86.40 \\
56.14 \\
66.70 \\
77.76 \\
83.02 \\
80.64 \\
88.32 \\
86.40 \\
68.16 \\
78.72 \\
99.34 \\
112.78\end{array}$ & $\begin{array}{r}56.14 \\
115.20 \\
98.84 \\
100.76 \\
102.72 \\
127.18 \\
142.08 \\
143.50 \\
142.54 \\
101.76 \\
147.84 \\
143.96 \\
186.20\end{array}$ & $\begin{array}{l}46.81 \\
40.85 \\
53.72 \\
58.33 \\
48.16 \\
42.74 \\
47.79 \\
50.48 \\
48.36 \\
42.83 \\
65.57 \\
56.38 \\
52.52\end{array}$ & $\begin{array}{l}34.23 \\
52.27 \\
47.56 \\
56.85 \\
58.80 \\
49.93 \\
61.58 \\
69.17 \\
64.87 \\
62.90 \\
61.19 \\
68.78 \\
65.84\end{array}$ & $\begin{array}{r}81.04 \\
93.12 \\
107.44 \\
115.18 \\
106.96 \\
92.67 \\
109.37 \\
119.65 \\
113.23 \\
105.73 \\
126.76 \\
125.16 \\
118.36\end{array}$ & $\begin{array}{r}6.29 \\
11.76 \\
22.93 \\
19.86 \\
12.02 \\
18.87 \\
29.36 \\
27.85 \\
27.14 \\
14.39 \\
45.32 \\
25.15 \\
38.56\end{array}$ & $\begin{array}{l}18.18 \\
45.16 \\
26.70 \\
37.91 \\
45.72 \\
41.45 \\
4965 \\
61.09 \\
56.04 \\
42.87 \\
48.11 \\
68.32 \\
74.25\end{array}$ & $\begin{array}{c}24.47 \\
56.92 \\
49.63 \\
57.77 \\
69.76 \\
60.32 \\
79.01 \\
88.94 \\
83.18 \\
57.26 \\
93.48 \\
93.47 \\
112.81\end{array}$ \\
\hline
\end{tabular}


Table - 3 Correlation values for some constituents of Cymbopogon nardus oil and phosphorus concentration in leaves $(\%)$ at the first harvest.

Compound

Nature of

Coefficient of correlation

correlation

Linallool

Positive

0.712

Borneol

Positive

0.528

Methyl iso-eugenol

Positive

0.508

Total geraniol

Positive

0.448

Total hydrocarbon

Negative

0.748

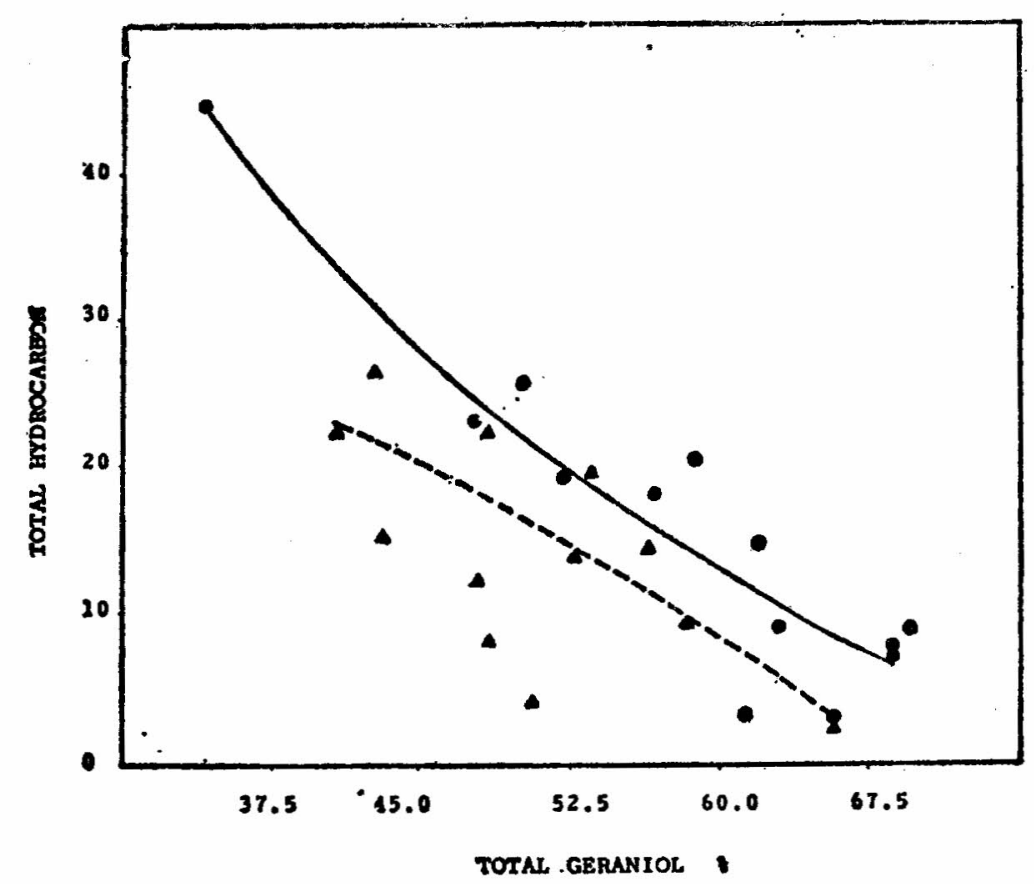

Figure 2. The relationship between total geraniol versus, total hydrocarbon at (i) first harvest $(-: \Delta)$ and (ii) second harvest (- O).

Output of total geraniol was affected positively by all four levels of phospborus nutrition (Table 2). As shown in Figure 3, a high positive correlation was observed between the phosphorus content in leaves and the output of total geraniol $(r=+0.59)$ and essential oil yield $(r=+0.58)$. No significant effect of magnesium fertilizers has been observed on the output of total geraniol. 
216

S. S. Ranaweera and W.P. Thilakaratne

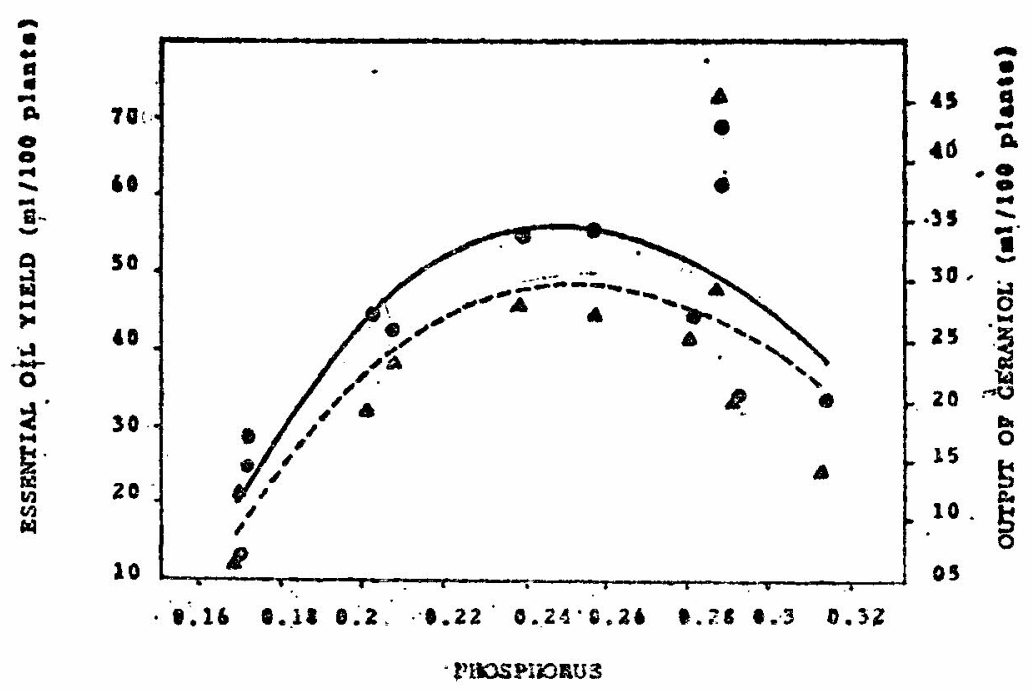

Fig. 3 The relationship between phosphours content in leaves verses essential oil yield $(-\ldots ;)$ and output of geranial $(--\infty)$ at the first harvest

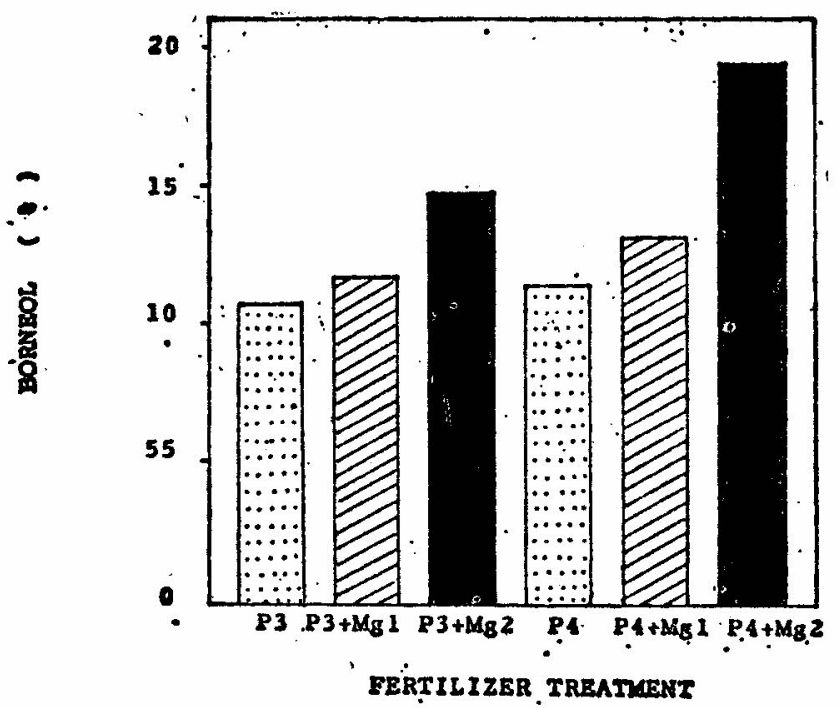

Fig. 4 Effect of $\mathrm{Mg}$ and $\mathrm{P}$ nutrition on the formation of borneol in Cymbopogon nards at the first harvest. 


\section{Discussion}

Our results have shown that phosphorus and magnesium nutrition of Cymbopogon nardus has increased the total geraniol content in its oil. The market quality of citronella oil is determined by its total geraniol content (Wijesekera, 1973). This increased production of total geraniol was mainly due to the increase of its constituents : borneol, linalool and methyl iso-euginol. Positive correlations were observed between leaf phosphorus and linalool $(\mathrm{r}=+0.71)$, borneol $(\mathrm{r}=+0.53)$ and methyl iso-euginol $(\mathrm{r}=+0.637)$ contents in oil (Table 3). Geranyl pyrophosphate has been shown to act as a specific precurssor of linalool (Hanson, 1967). The positive effect of phosphorus nutrition on geraniol (constituent of total geraniol) content in Cymbopogon winterianus oil has been previously reported (Chandra, 1972).

The combined effect of magnesium with phosphorus fertilizers on the total geraniol content in oil was significant at the second harvest. Fertilizer treatments with magnesium-phosphorus combinations have enhanced the production of borneol, linalool and elemol contents in citronella oil.

From our results, it is clearly observed that phosphorus nutrition had a positive effect on the output of total geraniol (Table 2). Magnesium has enhanced the oil production, when it was applied in combination with phosphorus fertilizers. This positive effect of phosphorus and magnesium nutrition on the essential oil production of citronella can be due to involvement of these ions in the biosynthesis of essential oils. Several phosphorylation reactions of precurssor compounds are involved in the essential oil biosynthesis and they are shown to be dependant upon adenosine triphosphate (ATP), reduced pyridine nucleotides and magnesium ions (Am dur et al, 1957). As observed in Fig. 1, the negative relationship of hydrocarbons and the positive relationship of total geraniol with the phosphorus content in leaves of $C$. nardus, indicate the involvement of phosphorus in the bio-synthesis of constituents of total alcohols, through better utilization of hydrocarbons by this plant. The conversion of mineral phosphorus into organic phosphorus compounds in soybeans has shown to be enhanced by magnesium fertilizers (Ranaweera \& Threshov, 1977)

The optimum concentrations of leaf phosphorus that produced maximum yields of essential oil and total geraniol were found to be in the range of 0.23 to $0.26 \%$, at the first harvest, four months after planting (Fig 3).

It is clear from our experimental results that phosphorus and magnesium nutrition is effective on the production of essential oil by Cymbopogon nardus and also it improves the market quality of oil by increasing its total geraniol content. Further extensive field experimentation is needed, in order to recommend optimum fertilizer dozes for citronella crop. 


\section{Acknowledgement}

This study was supported by a research grant from the University of Sri Jayewardenepura (USJ). We are thankfull to Mr. J.P. N. Jayaweera of Department of Chemistry, USJ and Dr. U. Senanayake and Mr. K. R. Dayananda of Ceylon Institute for Scientific and Industrial Research (CISIR), Colombo for assisting us in GLC work.

\section{References}

1. Abeywikrama, B.A., 1959. A Provsional Check List of the Flowering Plants of Ceylon. J. Science (Biol. Sci), 2 (2): 119-140.

2. Brain, K.R. and T.D.Turner, 1975. Determination of Essential Oil Content : The Practical Evaluation of Phytopharmaceuticals Bristol, Wright-Scientechnica, 86-87.

3. Brown, E. and W.S.A. Mathews, 1951. Notes on the Aromatic Grasses of Commercial Importance. Colonial Plants and Animal Products, 2:178-181.

4. Chandra, V., 1972. Effect of Varying Concentration of N.P.K. Fertilizer on yield and oil of Cymbopogon winterianus Jowitt. Indian Perfumer, 16 (1) : 52-56.

5. Guenther, E., 1950. The Essential Oils. New York, Van Nostrand, $4: 67$.

6. Heses, P.R., 1971. A textbook of soil chemical analysis, London; John murray.

7. Hanson, J. R., 1967. The Biosynthesis of the Monoterpenes. Perfum. and Ess. oil Res., Nov. 787-795.

8. Iruthayathas, E. E., H. M. W. Herath, R. O. B. Wi jesekera, and A. L. Jayawardene, 1977. Variation in the Composition of Oil in Citronella. J. Natn. Sci. Coun. Sri Lanka, 5 (2) : 133-146.

9. Jowitt, J. F., 1908. The Volatile Oils (Gildemeister, A. and Hoffman, A. eds., Kremere, E., transl.), 2nd Edn., 2 : 217-243, Annals Royal Botaanical Gardens, Peradeniya, 41:185.

10. Peterburski, A.V., 1968. Determination of Available Phosphorus in Kraznoseom soils. Prakticum po Agronomicheskoi Chemie. 6th Edn,, Moskva Isdatelstvo "Kolos."

11. Ranaweera. S.S. and A.G.Threshov, 1977. The Effects of Magnesium and Phosphorus Nutrition on the Fraztional Composition of Magnesium and Phosphorus in Soybean Plant. Problemie Tropicheskoi i Subtropicheskoi Kulturie, 136 (10): 3-7.

12 Ranaweera, S, S. and W.P.Thilakaratne 1992. Mineral Nutrition of Cymbopogon nardus (L) Rendle : I Effects of Magnesium and Phosphorus Nutrition on Growth and the Yield of Essential Oil. Vidyodaya J.Science, (in Press)

13. Wijesekera R.O.B., 1973. The Chemical Composition and Analysis of Citronella Oil. J. Natn. Sci. Coun. Sri Lanka, 1 : 67-81. 